\title{
Dry Feeds Produced Based on Local Available Feedstuffs for African Catfish Clarias Gariepinus Juveniles Rearing in Earthen Ponds
}

\author{
E. M.-A. N'Gbaramou, A. R. Koumi, B. C. Atsé, and K. Tano
}

\begin{abstract}
The aim of this study was to produce a suitable low-cost feeds for African catfish Clarias gariepinus rearing in Côte d'Ivoire fish farms. Three isoproteic (35\% protein level) dry feeds were formulated and produced with the local available feedstuffs of Sudano Guinean 1 (SG1), Sudano Guinean 2 (SG2) and Guinean (G) Côte d'Ivoire agro ecological areas. Then, Clarias gariepinus juveniles initial mean weight $12.98 \pm 1.23 \mathrm{~g}$ were fed with these three feeds at $5 \%$ of the total biomass two times (9:00 am and 05:00 pm) per day during 120 days. Each feed was hand distributed in the triplicate fish groups stocked in earthen ponds at $3 \mathrm{fish} / \mathrm{m}^{2}$. At the end of the trial, growth data showed significant higher growth with fish fed feeds G and SG2 than those of fish fed feed SG1. The weight gains of fish varied between $459.95 \pm$ 101.31 (SG1) and $664.74 \pm 67.45$ (G) $\mathrm{g}$ with the daily weight gain oscillated between $3.83 \pm 0.84$ (SG1) and $5.54 \pm 0.56$ (G) g/day. The best feed efficiency values were recorded with fish fed feeds G and SG2. Nutritional compositions recorded from the body of fish fed feed $G(21.46 \pm 0.01 \%)$ showed highest protein values when the body of fish fed with feed SG1 presented the highest moisture (77.92 $\pm 0.17 \%$ ) and crude lipid $(1.77 \pm 0.14 \%)$ contents. Results showed that the three feeds produced were suitable for a good growth of Clarias gariepinus juveniles rearing in earthen ponds, however, the best growth and feeds efficiency results were recorded with feeds G and SG2.
\end{abstract}

Index Terms - Clarias gariepinus juveniles, local feedstuffs, feeds, growth.

\section{INTRODUCTION}

Catfish generally are low rearing in Côte d'Ivoire because of the acknowledgement of their nutritional needs and their growth potential by fish farmers [1] - [4]. Also, consequently of the lack of quality feeds adapted to the different stages of catfish growth, feeds used for tilapia farming are also used by fish farmers to feed catfish [2], [1], [5]. So, local feed sellers feeds and fish farmers or agroindustrial by-products which are in general no suitable and no competitive for these fish growth are used [6], [7], [1].

In these last 5 years, adapted quality granulated and extruded catfish feeds are imported and sold on local markets [1], [8]. However, their high prices make them inaccessible to the most of fish farmers, which are generally

Published on July 1, 2020.

E. M.-A. N'Gbaramou, Université Nangui Abrogoua (UNA), Côte D'Ivoire.

A. R. Koumi, Centre de Recherches Océanologiques (CRO), Côte D'Ivoire.

(corresponding e-mail: koumirachel ${ }^{@}$ yahoo.fr).

B. C. Atsé, Centre de Recherches Océanologiques (CRO), Côte D'Ivoire.

K. Tano, Université Nangui Abrogoua (UNA), Côte D’Ivoire. farmers [4]. Furthermore, quality and price ratios of the feeds used plays a very important role in fish farming and represents 60 to $70 \%$ of production costs in some of the developing countries [9], [10]. In addition, fish feeds have always been one of the major inputs to the successful of fish farming [10] - [12]. So, the national needs to improve growth and production of farming fish in Côte d'Ivoire reflect the needs to develop local competitive catfish feeds for the expansion of catfish farming.

Furthermore, nutritional requirements of all rearing stages of catfish Clarias gariepinus are well documented [13], [14], [7], [6]. In Addition, Sudano Guinean 1 (SG1), Sudano Guinean 2 (SG2) and Guinean (G) agro ecological areas of Côte d'Ivoire were reported as the areas of high concentrations of fish farmers and high level of fish farming activities [3], [4]. According to [12] and [11], the use of locally available ingredients in composed fish feeds formulations reduce feeds cost and fish production financial charges. Also, [15] reported that aquaculture production could profitable if fish farmers had access to quality feeds for increase fish growth at a least cost.

While, the availability and costs of animal feedstuffs vary by region and by area in the same country. The aim of this study was to formulate low-cost quality feeds with locally accessible feedstuffs for Clarias gariepinus juveniles rearing in the three fish farming agro ecological areas of Côte d'Ivoire.

\section{MATERIAL AND METHODS}

\section{A. Experimental fish and rearing conditions}

Fish used for this feeding trial were the juveniles of Clarias gariepinus with an initial weight ranging between 12.55 and $13.54 \mathrm{~g}$. Feeding trials were carried out in one private fish farm at $40 \mathrm{~km}$ near Abidjan. Rearing was realized in the same conditions of fish production that the fish farmers during 120 days in earthen ponds. Total of nine ponds of $242 \mathrm{~m}^{2}$ to $252 \mathrm{~m}^{2}$ were supply in fresh water and used for the trial.

\section{B. Feeds formulation and production}

In the three fish farming areas, the feedstuffs were chosen on the basis of their availability and cost (Table I) and nutritional composition (Table II) for the low cost locally quality fish feeds formulations. All selected feedstuffs were separately grinded then analyzed for proximate composition determination. Linear programming feeds formulas determination method described by [16] was used to formulate three isoprotein (35\% crude protein) feeds based 
on the Clarias gariepinus juveniles nutriments requirement of 6-10\% crude lipid, $25-30 \%$ nitrogen free extract, less of $10 \%$ crude fibre, $8-10 \%$ Ash, $20-25 \mathrm{~kJ} / \mathrm{g}$ gross energy and protein energy (P/E) ratio more or equal to $20 \mathrm{mg} / \mathrm{kJ}$ according to [13], [17], [18] and [6]. All feedstuffs selected were individually grounded into fine flour and weighted based on formulas determined. Then, all the feedstuffs according to feeds composition determined were mixed at $500 \mathrm{~kg} / 30 \mathrm{mn}$ with the vertically animal feeds mixer. All composed feeds were presented on the pellet form of $2 \mathrm{~mm}$ diameter (Fig. 1). At the end of feeds production, one kilogram of each feeds was sampled and grounded into flour for proximate composition determination.
TABLE I: AVAILABILITY AND PRICE (USD/KG)* OF FEEDSTUFFS SELECTED BY AGRO ECOLOGICAL AREAS

\begin{tabular}{lccc}
\hline Feedstuffs & $\begin{array}{c}\text { Sudano- } \\
\text { Guinean } \\
1 \text { area }\end{array}$ & $\begin{array}{c}\text { Sudano- } \\
\text { Guinean } \\
2 \text { area }\end{array}$ & $\begin{array}{c}\text { Guinean } \\
\text { area }\end{array}$ \\
\hline Imported fish meal $(55 \%$ P) & $1.16++$ & $1.16++$ & $1.06+++$ \\
Local market fish meal (42\% P) & $0.50++$ & $0.50++$ & $0.50++$ \\
Soybean meal & $0.61++$ & $0.70++$ & $0.67+++$ \\
Cotton seed oil cake & $0.33++$ & $0.33+++$ & $0.39+++$ \\
Cashew nut oil cake & - & $0.33+++$ & $0.33++$ \\
Wheat bran & $0.19++$ & $0.22++$ & $0.20+++$ \\
White rice bran & $0.05+++$ & - & $0.10+$ \\
\hline
\end{tabular}

*1USD $=602.08$ FCFA based on May 2020.

+availability of feedstuffs.

TABLE II: PROXIMATE COMPOSITION (G/100 G DRY MATTER) OF FEEDSTUFFS USED FOR FEEDS FORMULATION

\begin{tabular}{|c|c|c|c|c|c|c|c|}
\hline Parameters & $\begin{array}{c}\text { Imported fish } \\
\text { meal } \\
(55 \% \mathrm{P}) \\
\end{array}$ & $\begin{array}{c}\text { Local market } \\
\text { fish meal } \\
(42 \% \mathrm{P})\end{array}$ & $\begin{array}{c}\text { Soybean } \\
\text { meal }\end{array}$ & $\begin{array}{l}\text { Cotton seed } \\
\text { oil cake }\end{array}$ & $\begin{array}{c}\text { Cashew nut } \\
\text { oil cake }\end{array}$ & $\begin{array}{l}\text { Wheat } \\
\text { bran }\end{array}$ & $\begin{array}{c}\text { White rice } \\
\text { bran }\end{array}$ \\
\hline Moisture (\%) & $11.23 \pm 0.21$ & $8.92 \pm 0.56$ & $11.89 \pm 0.50$ & $9.66 \pm 0.51$ & $6.14 \pm 0.51$ & $10.84 \pm 0.32$ & $9.88 \pm 0.22$ \\
\hline Crude protein $(\%)$ & $55.30 \pm 0.12$ & $42.67 \pm 1.00$ & $44.56 \pm 2.29$ & $35.71 \pm 0.73$ & $19.87 \pm 1.74$ & $15.97 \pm 0.93$ & $11.95 \pm 1.77$ \\
\hline Crude fibre $(\%)$ & $2.39 \pm 0.61$ & $4.84 \pm 0.83$ & $4.67 \pm 0.40$ & $24.58 \pm 0.25$ & $6.08 \pm 0.32$ & $20.32 \pm 0.35$ & $10.37 \pm 0.28$ \\
\hline Crude lipid (\%) & $9.05 \pm 0.71$ & $14.59 \pm 0.88$ & $1.74 \pm 0.51$ & $3.01 \pm 0.10$ & $38.90 \pm 0.36$ & $4.64 \pm 0.03$ & $14.27 \pm 1.76$ \\
\hline $\operatorname{Ash}(\%)$ & $21.15 \pm 0.98$ & $29.17 \pm 0.12$ & $6.09 \pm 0.16$ & $5.93 \pm 1.46$ & $3.21 \pm 0.18$ & $5.12 \pm 0.02$ & $8.75 \pm 1.05$ \\
\hline NFE1 $(\%)$ & $0.99 \pm 0.46$ & $0.51 \pm 0.40$ & $31.32 \pm 3.27$ & $21.10 \pm 1.79$ & $26.73 \pm 1.23$ & $43.27 \pm 1.61$ & $44.68 \pm 2.67$ \\
\hline *Energy $(\mathrm{kJ} / \mathrm{g})$ & $17.26 \pm 0.10$ & $16.67 \pm 0.31$ & $17.44 \pm 0.25$ & $17.52 \pm 0.40$ & $25.48 \pm 0.01$ & $16.53 \pm 0.01$ & $17.93 \pm 0.42$ \\
\hline
\end{tabular}

1 Nitrogen Free Extract $=100$ - (moisture + crude protein + crude lipid + crude fibre + Ash $)$.

* Gross energy was calculated on the basis of $23.7 \mathrm{~kJ}_{\text {gprotein }}^{-1}, 39.5 \mathrm{~kJ} \mathrm{glipid}^{-1}, 17.2 \mathrm{~kJ}$ gcarbohydrate $^{-1}$.

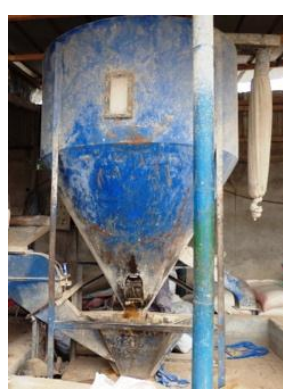

a)

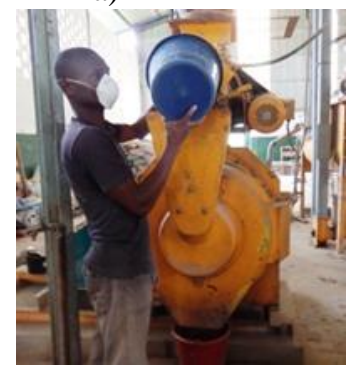

d)

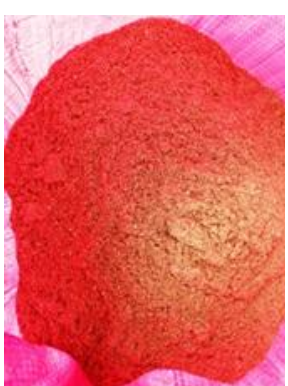

b)

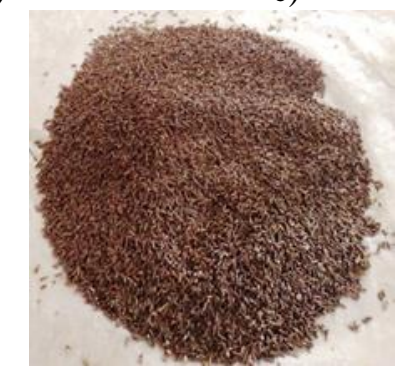

e)

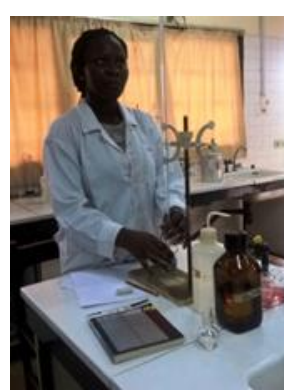

c)
Fig. 1. a) Vertically animal feeds mixer; b) Composed fish feed mixed, c) Crude protein level determination; d) Fish feeds granulation; e) $2 \mathrm{~mm}$ pelleted fish feed.

\section{Feeding trial}

Nine groups of 726 to 756 of Clarias gariepinus juveniles with an average weight $12.98 \pm 1.23 \mathrm{~g}$ were randomly distributed into ponds at a density of 3 fish per $\mathrm{m}^{2}$. The fish were fed two times a day (9:00 am and 05:00 pm) at 5\% of fish total biomass by pond 120 days. One fish feed treatment was replicate in three ponds. All days, the fish dead were collected by ponds and counted. Water quality parameters such as temperature, dissolved oxygen, $\mathrm{pH}$, salinity, Total Disolved Solid and conductivity were weekly measured using a multiparameter HANNA. After all 30 days of feeding, $30 \%$ of fish in each pond were collected and fish were individual weighed and measured. Then the new total biomass of fish by pond and the new feeds quantities to distribute by pond were calculated. At the end of the feeding trial, the samples of 10 fish by pond were sacrificed for body composition analysis.

\section{Growth performance and feed efficiency}

Fish growth characteristics, feed utilization and survival rate were determined as follows: Weight Gain $(\mathrm{WG})(\mathrm{g})=$ Final body weight - Initial body weight; Biomass Gain (BG) $(\mathrm{kg})=$ Final biomass - Initial biomass; Lenght Gain (LG) $(\mathrm{cm})=$ Final length - Initial length; Daily Weight Gain (DWG) $\left(\mathrm{g} \mathrm{day}^{-1}\right)=($ Final body weight - Initial body weight)/(Number of feeding day); Daily Length Gain (DLG) $\left(\mathrm{cm} \mathrm{day}{ }^{-1}\right)=($ Final length - Initial length $) /($ Number of feeding day); Specific Growth Rate (SGR) $\left(\%\right.$ day $\left.^{-1}\right)=[\ln$ (Final body weight) - $\ln$ (Initial body weight)] $\times$ 100/Number of feeding day; Feed Conversion Ratio (FCR) $=$ Total weight of feed distributed $(\mathrm{kg}) /$ Biomass gain $(\mathrm{kg})$; Protein Efficiency Ratio $(\mathrm{PER})=$ Biomass gain/Dietary protein intake; Survival Rate $(\mathrm{SR})(\%)=($ Final number of fish /Initial number of fish) $\times 100$.

\section{E. Biochemical analysis}

Proximate composition for all feedstuffs, feeds composed and fish body samples were analyzed according to standard procedures described in [19]. Dry matter percentage was determined after oven drying at $105^{\circ} \mathrm{C}$ during 24 hours until constant weight; crude protein ( $\% \mathrm{~N}$ x 6.25) was determined using kjeldahl method; crude lipid by Soxhlet extraction with hexane; Ash was measured by incineration at $550^{\circ} \mathrm{C}$ in a muffle furnace for 24 hours; crude fibres rates were measured by acid digestion following by ashing the dry residue at $550^{\circ} \mathrm{C}$ in a muffle furnace for $4 \mathrm{~h}$, while nitrogenfree extract (NFE) were calculated by difference. The gross energy contents of the diets were calculated on the basis of 
their crude proteins, lipid and carbohydrate contents using the energy equivalents of 23.7, 39.5 and $17.2 \mathrm{kJg}^{-1}$ respectively.

\section{F. Data analysis}

Statistical analysis of data collected was performed with STATISTICA 7.1 software. Data were expressed as means \pm standard deviation. One-way analysis of variance (ANOVA) was used to compare the values. Then, Duncan multiple range tests were used to compare differences among means. Differences were considered significant at $\mathrm{p}<0.05$.

\section{RESULTS}

\section{A. Fish feeds formulas, quality and cost price}

The formulas and the proximate composition of the three feeds produced were showed in Table III. Soybean meal and cotton seed oil cake were used at different levels in the three feeds formulas, imported fish meal was used only in the two formulas (SG1; G), and also, cashew nut oil cake was used only for feeds SG2 and G formulation. The local market fish meal (42\% P) was used only in the SG2 feed, wheat bran used only in the feed $\mathrm{G}$ when white rice bran meal was used only in feed SG1. The $35 \%$ of the three feeds protein level in three diets were in according to the formulation objectives. At the end of feeds formulation, significant differences were found between all the other nutritional compositions parameters of the three feeds. The significant highest $(p<0.05)$ values of crude lipid, NFE, and gross energy were recorded with feed $G$ when the highest $(p<0.05)$ values of crude fibre, Ash and $\mathrm{P} / \mathrm{E}$ ratio were observed with feeds SG2. The significant lowest values of moisture, crude fibre, Ash, and P/E ratio were recorded with feed G; feed SG2 presented the lowest values of NFE and gross energy when feed SG1 had the lowest values of crude lipid. The feeds costs prices were oscillated between 0.52 $\mathrm{USD} / \mathrm{kg}$ (SG1) and $0.56 \mathrm{USD} / \mathrm{kg}(\mathrm{G})$.

\section{B. Water quality}

The Table IV shows the values of water quality parameters recorded in the feeding trial earthen ponds. There were had no significant difference $(\mathrm{p}>0.05)$ in the values of water temperature $\left(29.49 \pm 1.01-29.99 \pm 1.11^{\circ} \mathrm{C}\right)$, $\mathrm{pH}(8.52 \pm 1.29-9.19 \pm 1.04)$, salinity $(0.00 \% \mathrm{\%})$ and dissolved oxygen $(7.59 \pm 2.04-9.13 \pm 2.58 \mathrm{mg} / \mathrm{l})$. However, significant difference $(p<0.05)$ were observed with the TDS and conductivity values. The ponds received feeds SG1 $(46.00 \pm 10.20 \mu \mathrm{s} / \mathrm{cm})$ and SG2 $(34.14 \pm 8.67 \mu \mathrm{s} / \mathrm{cm})$ presented the higher means values of conductivity than those of ponds received feed $\mathrm{G}(32.57 \pm 8.68 \mu \mathrm{s} / \mathrm{cm})$. The ponds received the feeds SG1 $(25.57 \pm 2.68 \mathrm{mg} / \mathrm{l})$ recorded also higher means value of total dissolved solids than ponds which received feeds SG2 and G.
TABLE III: FORMULATION, PROXIMATE COMPOSITION AND COSTS PRICES OF FEEDS PRODUCED FOR CLARIAS GARIEPINUS JUVENILES REARING IN EARTHEN PONDS FOR SUDANO-GUINEAN 1 AREA (SG1), SUDANO-GUINEAN 2 AREA (SG2) AND GUINEAN AREA (G) OF CÔTE D'IVOIRE Fish feeds formulated

\begin{tabular}{|c|c|c|c|}
\hline \multirow[b]{2}{*}{ Feedstuff used } & \\
\hline & SG1 & SG2 & G \\
\hline $\begin{array}{l}\text { Imported fish meal } \\
(55 \% \mathrm{P})\end{array}$ & 25 & - & 20 \\
\hline $\begin{array}{l}\text { Local market fish } \\
\text { meal }(42 \% \mathrm{P})\end{array}$ & - & 35 & - \\
\hline Soybean meal & 25 & 35 & 25 \\
\hline Cotton seed oil cake & 20 & 15 & 20 \\
\hline Cashew nut oil cake & - & 15 & 25 \\
\hline Wheat bran & - & - & 10 \\
\hline White rice bran meal & 30 & - & - \\
\hline \multicolumn{4}{|c|}{ Proximate composition of feeds produced } \\
\hline Moisture (\%) & $8.20 \pm 0.16^{\mathrm{c}}$ & $7.20 \pm 0.16^{\mathrm{b}}$ & $6.50 \pm 0.29^{\mathrm{a}}$ \\
\hline Crude protein $(\%)$ & $35.66 \pm 0.54^{\mathrm{a}}$ & $35.44 \pm 0.09^{\mathrm{a}}$ & $35.22 \pm 0.16^{\mathrm{a}}$ \\
\hline Crude fibre (\%) & $7.45 \pm 0.37^{\mathrm{b}}$ & $8.65 \pm 0.26^{c}$ & $4.45 \pm 0.11^{\mathrm{a}}$ \\
\hline Crude lipid (\%) & $7.77 \pm 0.18^{\mathrm{a}}$ & $10.68 \pm 0.26^{\mathrm{b}}$ & $12.90 \pm 0.08^{c}$ \\
\hline $\operatorname{Ash}(\%)$ & $10.46 \pm 0.14^{\mathrm{b}}$ & $18.43 \pm 0.02^{\mathrm{c}}$ & $6.47 \pm 0.08^{\mathrm{a}}$ \\
\hline NFE $(\%)$ & $30.46 \pm 0.38^{\mathrm{b}}$ & $19.61 \pm 0.23^{\mathrm{a}}$ & $34.46 \pm 0.14^{\mathrm{c}}$ \\
\hline $\begin{array}{l}\text { Gross energy** } \\
(\mathrm{kJ} / \mathrm{g})\end{array}$ & $18.04 \pm 0.01^{\mathrm{b}}$ & $17.48 \pm 0.34^{\mathrm{a}}$ & $20.14 \pm 0.03^{\mathrm{c}}$ \\
\hline $\mathrm{P} / \mathrm{E}(\mathrm{mg} / \mathrm{kJ})$ & $19.77 \pm 0.18^{\mathrm{b}}$ & $20.28 \pm 0.07^{c}$ & $17.49 \pm 0.04^{\mathrm{a}}$ \\
\hline $\begin{array}{l}\text { Cost price } * * * \\
\text { (USD/kg) }\end{array}$ & 0.52 & 0.53 & 0.56 \\
\hline
\end{tabular}

**Gross energy was calculated on the basis of $23.7 \mathrm{kJg}^{-1}$ for protein, 39.5 $\mathrm{kJg}^{-1}$ for lipid, $17.2 \mathrm{kJg}^{-1}$ for carbohydrates.

$* * * 1$ USD $=602.08$ FCFA based on May 2020. The grinding, mixing, pelleting and bagging charges were included by adding 0.025 USD on the price cost of feeds $\mathrm{kg}$ due to the types and quantities of feedstuffs used.

Means values in the same row having the common superscript letter are not significantly different $(\mathrm{p}>0.05)$.

TABLE IV: WATER QUALITY FLUCTUATIONS IN EARTHEN PONDS WHERE CLARIAS GARIEPINUS JUVENILES WERE FED WITH FORMULATED FEEDS FOR SUDANO-GuINEAN 1 AREA (SG1), SUDANO-GUINEAN 2 AREA (SG2) AND GuINEAN AREA (G) OF CÔTE D'IVOIRE DURING 120 DAYS

\begin{tabular}{|c|c|c|c|}
\hline \multirow{2}{*}{ Parameters } & \multicolumn{3}{|c|}{ Fish feeds used } \\
\hline & SG1 & SG2 & G \\
\hline Temperature $\left({ }^{\circ} \mathrm{C}\right)$ & $29.49 \pm 1.01^{\mathrm{a}}$ & $29.99 \pm 1.11^{\mathrm{a}}$ & $29.97 \pm 1.29^{\mathrm{a}}$ \\
\hline $\mathrm{pH}$ & $8.52 \pm 1.29^{\mathrm{a}}$ & $9.10 \pm 0.94^{\mathrm{a}}$ & $9.19 \pm 1.04^{\mathrm{a}}$ \\
\hline Salinity (\%o) & $0.00 \pm 0.01^{\mathrm{a}}$ & $0.00 \pm 0.01^{\mathrm{a}}$ & $0.00 \pm 0.01^{\mathrm{a}}$ \\
\hline Conductivity ( $\mu \mathrm{s} / \mathrm{cm})$ & $46.00 \pm 10.20^{\mathrm{b}}$ & $34.14 \pm 8.67^{\mathrm{ab}}$ & $32.57 \pm 8.68^{a}$ \\
\hline Dissolved oxygen (mg/l) & $7.59 \pm 2.04^{\mathrm{a}}$ & $9.08 \pm 2.28^{\mathrm{a}}$ & $9.13 \pm 2.58^{\mathrm{a}}$ \\
\hline $\begin{array}{l}\text { Total dissolved solids } \\
\text { TDS (mg/l) }\end{array}$ & $25.57 \pm 2.68^{b}$ & $18.29 \pm 3.59^{\mathrm{a}}$ & $17.29 \pm 4.68^{\mathrm{a}}$ \\
\hline
\end{tabular}

Values are presented as mean $\pm \mathrm{SE}$.

Means values in the same row having the common superscript letter are not significantly different $(\mathrm{p}>0.05)$.

\section{Growth and feed utilization parameters}

Fig. 2 and Table $\mathrm{V}$ show growth and feed utilization responses of $C$. gariepinus juveniles fed in earthen ponds with the three formulated feeds. The three groups of fish fed presented similar trends of growth evolution. However, significant differences $(p<0.05)$ were observed in monthly growth rate of fish with the type of feed received (Figure 1). So maximum monthly weight gains of fish were observed during the fourth month of feeding with feed SG1 (472.80 g) and during the third $(356.47 ; 314.93 \mathrm{~g})$ and fourth $(667.60$; $677.59 \mathrm{~g}$ ) months with the feeds SG2 and G. The significant $(p<0.05)$ lower growth of fish was recorded with feed SG1 
$(186.10 \mathrm{~g})$ during the third month of feeding trial compared to the growth of fish received the two other feeds. At the end of the feeds trial, significant $(\mathrm{p}<0.05)$ highest values of final body weight, final length, final biomass, weight gain, biomass gain, length gain, daily weight gain, specific growth rate and protein efficiency ratio were recorded with fish fed with feeds SG2 and G when fish fed feed SG1 recorded the lowest values (Table 3 ). The best values of feed conversion ratio were also recorded with fish fed feeds SG2 (1.01 \pm 0.19$)$ and $\mathrm{G}(1.09 \pm 0.23)$. The survival rates of fish fed were varied between $99.10 \pm 0.45 \%$ (SG1) and $99.26 \pm 0.08 \% \quad$ (SG2) without significant difference.

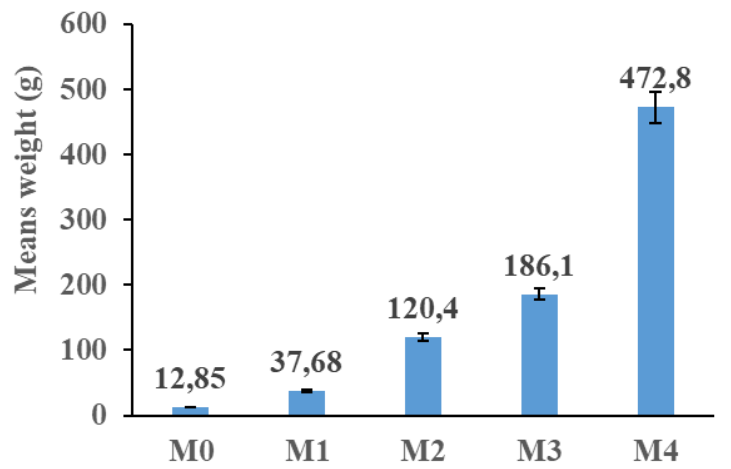

a)

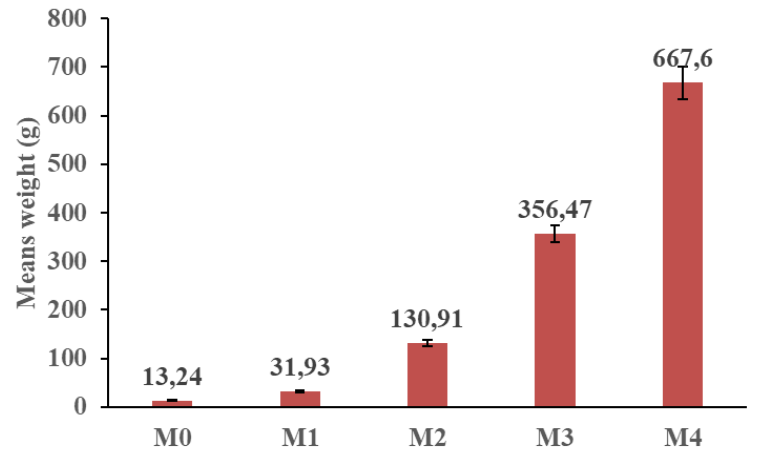

b)

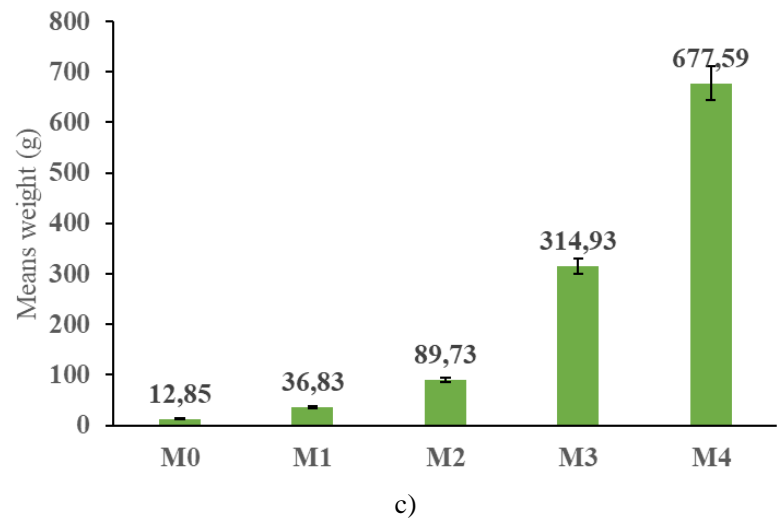

Fig. 2. Monthly growth response of $C$. gariepinus juveniles fed in earthen ponds with formulated feeds for Sudano-Guinean 1 area (a), SudanoGuinean 2 area (b) and Guinean Area (c) of Côte d'Ivoire during 120 days.
TABLE V: GROWTH PERFORMANCE AND FEED UTILIZATION VALUES OF CLARIAS GARIEPINUS JUVENILES FED IN EARTHEN PONDS WITH FORMULATED FEEDS FOR SUDANO-GUINEAN 1 AREA (SG1), SUDANO-GUINEAN 2 AREA

(SG2) AND GUINEAN AREA (G) OF CÔTE D'IVOIRE DURING 120 DAYS

\begin{tabular}{|c|c|c|c|}
\hline \multirow[b]{2}{*}{ Parameters } & \multicolumn{3}{|c|}{ Fish feeds used } \\
\hline & SG1 & SG2 & $\mathrm{G}$ \\
\hline $\begin{array}{l}\text { Initial body } \\
\text { weight }(\mathrm{g})\end{array}$ & $12.85 \pm 0.30^{\mathrm{a}}$ & $13.24 \pm 0.24^{\mathrm{a}}$ & $12.85 \pm 0.33^{\mathrm{a}}$ \\
\hline $\begin{array}{l}\text { Final body } \\
\text { weight }(\mathrm{g})\end{array}$ & $472.80 \pm 101.31^{\mathrm{a}}$ & $667.6 \pm 33.00^{\mathrm{b}}$ & $677.59 \pm 67.45^{\mathrm{b}}$ \\
\hline $\begin{array}{l}\text { Initial length } \\
(\mathrm{cm})\end{array}$ & $10.50 \pm 0.50^{\mathrm{a}}$ & $10.67 \pm 0.58^{\mathrm{a}}$ & $10.67 \pm 0.29^{\mathrm{a}}$ \\
\hline $\begin{array}{l}\text { Final length } \\
(\mathrm{cm})\end{array}$ & $34.96 \pm 2.70^{\mathrm{a}}$ & $40.15 \pm 2.87^{b}$ & $40.39 \pm 2.78^{b}$ \\
\hline $\begin{array}{l}\text { Initial biomass } \\
(\mathrm{kg})\end{array}$ & $10.46 \pm 0.62^{\mathrm{a}}$ & $10.78 \pm 1.01^{\mathrm{a}}$ & $10.40 \pm 1.24^{\mathrm{a}}$ \\
\hline $\begin{array}{l}\text { Final biomass } \\
(\mathrm{kg})\end{array}$ & $379.66 \pm 81.35^{\mathrm{a}}$ & $538.75 \pm 107.33^{b}$ & $544.10 \pm 134.46^{\mathrm{b}}$ \\
\hline Weight gain (g) & $459.95 \pm 101.31^{\mathrm{a}}$ & $654.36 \pm 33^{b}$ & $664.74 \pm 67.45^{b}$ \\
\hline $\begin{array}{l}\text { Biomass gain } \\
(\mathrm{kg})\end{array}$ & $369.20 \pm 81.35^{\mathrm{a}}$ & $527.98 \pm 107.33^{b}$ & $533.71 \pm 134.46^{\mathrm{b}}$ \\
\hline $\begin{array}{l}\text { Length gain } \\
(\mathrm{cm})\end{array}$ & $24.46 \pm 2.98^{\mathrm{a}}$ & $29.48 \pm 2.39^{b}$ & $29.72 \pm 3.03^{\mathrm{b}}$ \\
\hline $\begin{array}{l}\text { Daily weight } \\
\text { gain (DWG) (g } \\
\text { day-1) }\end{array}$ & $3.83 \pm 0.84^{\mathrm{a}}$ & $5.45 \pm 0.28^{b}$ & $5.54 \pm 0.56^{\mathrm{b}}$ \\
\hline $\begin{array}{l}\text { Daily length } \\
\text { gain (cm day-1) }\end{array}$ & $0.20 \pm 0.02^{\mathrm{a}}$ & $0.25 \pm 0.02^{\mathrm{b}}$ & $0.25 \pm 0.02^{\mathrm{b}}$ \\
\hline $\begin{array}{l}\text { Specific growth } \\
\text { rate (SGR) } \\
(\% / \text { day })\end{array}$ & $2.99 \pm 0.08^{\mathrm{a}}$ & $3.26 \pm 0.07^{\mathrm{b}}$ & $3.29 \pm 0.01^{\mathrm{b}}$ \\
\hline $\begin{array}{l}\text { Feed } \\
\text { conversion }\end{array}$ & & & \\
\hline $\begin{array}{l}\text { ratio (FCR) } \\
\text { Protein }\end{array}$ & $1.12 \pm 0.25^{\mathrm{a}}$ & $1.09 \pm 0.23^{\mathrm{a}}$ & $1.01 \pm 0.19^{\mathrm{a}}$ \\
\hline $\begin{array}{l}\text { efficiency ratio } \\
\text { (PER) }\end{array}$ & $2.59 \pm 0.57^{\mathrm{a}}$ & $2.67 \pm 0.54^{\mathrm{a}}$ & $2.89 \pm 0.54^{\mathrm{a}}$ \\
\hline $\begin{array}{l}\text { Survival rate } \\
(\%)\end{array}$ & $99.10 \pm 0.45^{\mathrm{a}}$ & $99.14 \pm 0.51^{\mathrm{a}}$ & $99.26 \pm 0.08^{\mathrm{a}}$ \\
\hline
\end{tabular}

Values are presented as mean \pm SE.

Means values in the same row having the common superscript letter are not significantly different $(\mathrm{p}>0.05)$.

\section{Proximate composition of fish}

The results of body composition of the fish after the feeding trial were presented in the Table VI. The significant differences ( $p>0.05)$ were observed between moisture, crude protein and crude lipid content of bodies of fish fed with the three feeds. The highest values of moisture $(77.92 \pm 0.17 \%)$ and crude lipid $(1.77 \pm 0.14 \%)$ were recorded with fish fed with the feed SG1 when the highest values of crude protein were recorded with fish fed feed G $(21.46 \pm 0.01 \%)$.

TABLE VI: BODY COMPOSITION OF CLARIAS GARIEPINUS JUVENILES FED IN EARTHEN PONDS WITH FORMULATED FEEDS FOR SUDANO-GUINEAN 1 AREA (SG1), SudANO-GuINEAN 2 AREA (SG2) AND GuinEAN AREA (G) OF CÔTE D'IVOIRE DURING 120 DAYS (\% WET WEIGHT)

\begin{tabular}{|c|c|c|c|}
\hline \multirow{2}{*}{ Parameters } & \multicolumn{3}{|c|}{ Fish feeds used } \\
\hline & SG1 & SG2 & $\mathrm{G}$ \\
\hline Moisture (\%) & $77.92 \pm 0.17^{\mathrm{b}}$ & $76.95 \pm 0.10^{\mathrm{a}}$ & $76.83 \pm 0.22^{\mathrm{a}}$ \\
\hline Crude protein $(\%)$ & $20.05 \pm 0.04^{\mathrm{a}}$ & $20.96 \pm 0.05^{\mathrm{a}}$ & $21.46 \pm 0.01^{\mathrm{b}}$ \\
\hline Crude lipid (\%) & $1.77 \pm 0.14^{\mathrm{b}}$ & $1.19 \pm 0.37^{\mathrm{a}}$ & $1.27 \pm 0.17^{\mathrm{a}}$ \\
\hline Ash $(\%)$ & $1.09 \pm 0.14^{\mathrm{a}}$ & $1.09 \pm 0.13^{\mathrm{a}}$ & $0.99 \pm 0.01^{\mathrm{a}}$ \\
\hline${ }^{*}$ Gross energy $(\mathrm{kJ} / \mathrm{g})$ & $5.45 \pm 0.06^{\mathrm{a}}$ & $5.44 \pm 0.15^{\mathrm{a}}$ & $5.59 \pm 0.07^{\mathrm{a}}$ \\
\hline
\end{tabular}

Values are presented as mean $\pm \mathrm{SE}$.

* Gross energy was calculated on the basis of $23.7 \mathrm{kJg}^{-1}$ for protein, 39.5 $\mathrm{kJg}^{-1}$ for lipid, $17.2 \mathrm{kJg}^{-1}$ for carbohydrates.

Means values in the same row having the common superscript letter are not significantly different $(\mathrm{p}>0.05)$. 


\section{DISCUSSION}

All the three feeds tested were formulated at $35 \%$ protein level and following requirement needs of crude lipid, NFE, crude fibre, crude Ash and gross energy of Clarias gariepinus juveniles reported by several authors [13], [14], [7], [6]. However, the nutritional composition of the three feeds produced reflected the nutritional composition of type and quantities of feedstuffs used as reported by [20]. So, the high level of lipid in feed G (12.90\%) and SG2 (10.68\%) could be due to the incorporation of 15 and $25 \%$ of local cashew nut oil cake, rich in the lipid (38.90\%). Also, high level of Ash of feed SG2 (18.43\%) could be due to the high level $(35 \%)$ of incorporation of local market fish meal rich in the Ash (29.17\%). However, this high level of Ash in feed is not the limit factors of the using of feed nutrients by fish because the excess of Ash in feeds are rejected into the rearing water. [21] achieved a good growth of hybrids $(C$. macrocephalus x C. gariepinus) with the 15.15 to $21.04 \%$ Ash levels in feeds.

Concerning the water quality in feeding trial ponds, the similar values of temperature, $\mathrm{pH}$, salinity and dissolved oxygen was due to the fact that all the ponds used were supply in water by the same dam. Otherwise, the values recorded in the ponds for these most important water parameters in aquaculture $(\mathrm{T}, \mathrm{pH}, \mathrm{DO})$ were within in the suitable ranges of recommended values for good growth of African catfish [22], [23]. Also, values (32.57-46 us/cm) recorded for the water conductivity in the feeding ponds were within in the conductivity values of natural waters ranged between 20-1500 us/cm [24]. According to [25], the levels of TDS in pond water is attributed to the use of feeds by fish and feeding have been reported to increase the level of TDS of water. So, the high levels of TDS values recorded in ponds where fish were fed with feed SG1 suggest a low use of this feed by fish or an easy disaggregation of this feed in water, reducing its availability for fish feeding.

The differences observed in the growth performance of the fish fed with the three feeds produced could be due to the nutritional differences in the composition of feeds. However, feeds SG2 and G recorded the highest values of growth parameters in spite of the great differences in the crude fibre, Ash, NFE, gross energy and P/E ratios in these two feeds. These growth performances could be attributed to the high lipid content $(10.68 \pm 0.26-12.90 \pm 0.08 \%)$ of these two feeds. In fact, lipids are known to be the preferred energy source for the development of tissues and body of fish by sparing protein [17], [26]. [27] also reported that dietary lipid played essential role in the growth and development of catfish. [28] and [29] reported that catfish larvaes growth depends both of dietary protein and lipids levels. Also, [30], recorded high growth of the Clarias gariepinus juveniles with the high level of lipid (more than $10 \%)$ in feeds. The similar growth performance recorded with feeds SG2 and G reveals the possibility to using up to $35 \%$ of low cost local market fish meal rich in Ash in the formulation of Clarias gariepinus juveniles feeds.

However, all the three simple composed feedstuffs feeds SG1, SG2 and G produced at $35 \%$ protein level without addition of mineral, vitamins and specific amino acid used for Clarias gariepinus juveniles recorded competitive growth performance (Daily Weight Gain = 3.83-5.54 g/day;
Specific Growth Rate=2.99-3.29 g/day) and feed efficiency values (Feeds Conversion Ratio $=1.01-1.12$ ) compared to those of several authors. In fact, [31], [6], [32], [33] and [34] reported daily weight gain values ranged between 1.43 to 7 $\mathrm{g} / \mathrm{j}$; specific growth rate values ranged between 1 to 2.56 $\% /$ day and feeds conversion ratio varied between 1.15 to 2.23 for the semi-intensive or intensive rearing of Clarias gariepinus juveniles of $10-18 \mathrm{~g}$ to the maximum of $620 \mathrm{~g}$ with $40 \%$ dietary protein level.

At the end of feeding trial, fish body moisture (76.83$76.95 \%)$, protein $(20.05-21.46 \%)$, lipid (1.19-1.77\%) and Ash (0.99-1.09 \%) values recorded were similar of those recorded by [6]. But results show that fish fed with feed $G$ which recorded the highest final body weight recorded also the highest body protein content. Also, the feed SG1 with the lowest level of lipid recorded the highest body lipid content. From the catfish, it had been reported a sparing of body lipids when dietary lipid is low. Also, [35], [36] and [37] reported that the fish use high levels of dietary lipid to reduce the activity of the hepatic lipogenesis enzymes to decrease of novo lipid synthesis when dietary lipids beyond $10 \%$. The similar body Ash content of fish at the end of the feeding trial confirms the releasing of the excess of Ash in feed SG2 into the rearing water.

\section{CONCLUSION}

The three feeds produced with local available feedstuffs were competitive and suitable for Clarias gariepinus juveniles rearing in earthen ponds. Results confirm the possibility to use local low cost cashew nut oil cake and local market fish meal to produce simple composed feeds for semi-intensive Clarias gariepinus rearing. The three feeds formulated can be made available to the Côte d'Ivoire fish farmers to promote the rearing of catfish Clarias gariepinus. However, quality of feed SG1 must be improved.

\section{ACKNOWLEDGMENT}

Authors express their gratitude to the FIRCA (Fonds Interprofessionnel pour la Recherche et le Conseil Agricole) for funding of this study. Authors also accord thanks to the AISA (Association Ivoirienne des Sciences Agronomiques) for the good management of the funds for this project and to the fish farmers for their help in this work.

\section{REFERENCES}

[1] A. R. Koumi, B. N. Kimou, B. C. Atsé, N. I. Ouattara, and P. L. Kouamé (April 2015). Fish Feeds Used in Côte d'Ivoire: Nature, Quality, Use and Productivity. Asian J. Agric. Food Sci. [Online]. 3 (2). $\quad$ pp 225-236. Available: https://ajouronline.com/index.php/AJAFS/article/view/2542.

[2] N. B. Kimou, R. A. Koumi, M. K. Koffi, C.B. Atsé, I. N. Ouattara and P. L. Kouamé (March -April2016). Utilisation des sous-produits agroalimentaires dans l'alimentation des poissons d'élevage en Côte d'Ivoire. Cah. Agric. [Online]. 25 (2) pp 1 - 9. Available: https://doi.org/10.1051/cagri/2016012.

[3] JICA. 2016. Rapport d'étude d'état des lieux de la pisciculture en Côte d'Ivoire. Projet de Relance de la production piscicole continentale en République de Côte d'Ivoire, OAFIC CO., LTD, INTEM Consulting, INC, 2016, 142p. 
[4] A. H. Yao, A. R. Koumi, B. C. Atsé, and E. P. Kouamelan (December 2017). État des connaissances sur la pisciculture en Côte d'Ivoire. Agron. Afr. [Online]. 29 (3) pp 227-244. Available : https://www.ajol.info/index.php/aga/article/view/164967.

[5] A. R. Koumi, B. N. Kimou, I. N. Ouattara, K. M. Koffi, B. C. Atsé and L. P. Kouamé (2016). Les aliments utilisés en pisciculture semi intensive en Côte d'Ivoire et leur productivité. Tropicultura [Online] 34 (3) pp 286-299. Available: http://www.tropicultura.org/content/v34n3.html

[6] C. Ducarme and J. C. Micha (2003). Technique de production intensive du poisson chat africain Clarias gariepinus. Tropicultura [Online]. $21 \quad$ (4) pp 189-198. Available: http://www.tropicultura.org/content/v21n4.html.

[7] S. Harpaz, "Catfish nutrition-aspects to consider". Proceeding of a Workshop on the Development of a Genetic Improvement Program for African Catfish Clarias gariepinus, ed. World Fish Center, pp. 79-8, Accra, 2007.

[8] R. A. Koumi, N. B. Kimou, I. N. Ouattara, C. B. Atsé and P. L. Kouamé (October 2017). Utilization of fish feeds by Côte d'Ivoire fish farmers and its influence on the quantitative competitive commercial fish production. Int. J. Biochem. Res. Rev. [Online]. 19 (3) pp 1-13. Available: https://doi.org/10.9734/IJBCRR/2017/36595.

[9] T. Hecht, 2013, "A review of on-farm feed management practices for North African catfish (Clarias gariepinus) in sub-Saharan Africa," in On-farm Feeding and Feed Management in Aquaculture, MR. Hasan and MB New, Ed. FAO Fisheries and Aquaculture Technical Paper, 2013, No. 583. pp. 463-479.

[10] J. Lazard (January-February 2014.) La diversité des fermes piscicoles mondiales illustrée par les cas de la Chine et du Nigéria. Cah. Agric. [Online]. 23 (1) pp 24-33. Available: https://doi.org/10.1684/agr.2014.0680.

[11] S. Craig and A. Helfrich, Understanding fish Nutrition, Feeds and Feeding; Virginia: Cooperation Extension, 2002

[12] U. U. Gabriel, O. A. Akinrotimi, D. O. Bekibele, D. N. Onunkwo and P. E. Anyanwu (July 2007). Aliments pour poissons produits localement : potentiels pour le développement de l'aquaculture en Afrique subsaharienne. Afr. J. Agric. Res. [Online]. 2 (7) pp 287 295. Available: https://academicjournals.org/journal/AJAR/articleabstract/5EB6DCD26937.

[13] M. B. New, Feed and feeding of fish and shrimp. A manual on the preparation and presentation of compound feeds for shrimp and fish in aquaculture; Rome: ADCP/REP, 1987. $\mathrm{N}^{\circ} 26,275 \mathrm{p}$

[14] C. L. Cahu (2004). Domestication et fonction de nutrition chez les poisons. INRA Productions Animales 17 pp 205-210.

[15] FAO, La situation mondiale des pêches et de l'aquaculture ; Rome : FAO, Département des pêches et de l'aquaculture, 2016, 241 p.

[16] A. R. Koumi, "Substitution de la farine de poisson par la farine de soja dans le régime alimentaire de Heterobranchus longifilis Valenciennes, 1840, Sarotherodon melanotheron Ruppell, 1852 et Oreochromis niloticus (Linne, 1758) : Influence sur la qualité du milieu d'élevage, croissance et croissance valeur nutritionnelle du poisson". PhD dissertation, U.F.R. Sciences et Technologies des Aliments., Université Nangui Abrogoua, Abidjan, Côte d'Ivoire, 2010.

[17] J. Guillaume, S. Kaushik, P. Bergot and R. Metailler, Nutrition et alimentation des poissons et crustacés ; Paris : INRA, 1999, 485 p.

[18] J. Lazard (Mars 2007). Aquaculture et espèce introduites: exemple de la domestication ex situ des tilapias. Cah. Agric. [Online].16 (2) pp 123-124. Available: https://doi.org/10.1684/agr.2007.0085.

[19] AOAC, Official methods of analysis. Association of Official Analytical Chemists; Washington DC: AOAC, 1990, 684 p.

[20] M. A. Hossain, S. Begum, M. N. Islam, and A. K.M. A Shah. (1998) Studies on the optimum protein to energy ratio of African catfish (Clarias gariepinus Burchell). Bangladesh J. Fish. Res. [Online]. 2 (1). pp 47-54. Available: http://aquaticcommons.org/16385/.

[21] U. Matchakuea and S. Koolkalya (2017). Utilization of shrimp shell substitute soybean for hybrid catfish (Clarias macrocephalus $\times$ Clarias gariepinus) diet. Inter. J. Agr. Tech. [Online]. 13 (7.1). pp 1103-1110. Available: http: //www.ijat-aatsea.com/pdf/v13_n7

[22] C. E. Boyd, Qualité de l'eau dans les étangs pour l'aquaculture; Alabama: Alabama Agricultural Experiment Station, Auburn University, Auburn, 1990, 1st Edn.

[23] N. M. Stone and H. K. Thomforde, Understanding your fish pond water analysis report; Arkansas: University of Arkansas Cooperative Extension, 2003, pp 1-4.

[24] J. F. N. Abowei (January 2010). Salinity, dissolved oxygen, pH and surface water temperature conditions in Nkoro River, Niger Delta, Nigeria. Adv. J. Food Sci. Technol. [Online]. 2(1). pp 16-21. Available:

https://maxwellsci.com/jp/abstract.php?jid=AJFST\&no=27\&abs=08.
[25] A. E. Ogbeidu and L. O. Edutie (2002). Effect of brewery effluent on the water quality and rotifers Ikpoba river, Southern Nigeria. Afr. J. Environ. Pollut. Health [Online].1 (1). pp 1-12. Available: http://www.academix.ng/documents/papers/1468920095_4679.pdf.

[26] A. O. Sotolu (2010). Feed utilization and biochemical characteristics of Clarias gariepinus (Burchell, 1822) fingerlings fed diet containing fish oil and vegetable oil as total replacements. $W$. $J$. Fish Marine Sc. [Online]. 2 (2). pp 93-98. Available: https://www.idosi.org/wjfms/wjfms2(2)10/4.pdf.

[27] Z. Pie, S. Xie, W. Lei, X. Zhu, Y. Yang, (Auguste 2004) Comparative study on the effect of dietary lipid level on growth and feed utilization for Gibel carp (Carassius auratus gibelio) and Chinese long snout catfish (Leiocassius logirostrisi Gunther). Aquac. Nutri.. [Online].10 (4). pp 209-216. Available: https://doi.org/10.1111/j.1365-2095.2004.00291.x.

[28] Y. B. Ossey, A. R. Koumi., K. M. Koffi, B. C. Atsé and L. P. Kouamé (Auguste 2012). Utilisation du soja, de la cervelle bovine et de l'asticot comme sources de protéines alimentaires chez les larves de Heterobranchus longifilis (Valenciennes, 1840). J. Anim. Plant. Sci. [Online]. 15 (1). pp 2099-2108. Available: http://www.m.elewa.org/JAPS/2012/15.1/Abstract3-atse.html.

[29] O. A. Achi., A. R. Koumi, Y. B. Ossey, W. Yté, N. I. Ouattara and B. C. Atsé (September -October 2017). Growth Performance and survival of Clarias gariepinus larvae fed with varying inclusions of beef brain meal. J. appl. biol. biotechnol. [Online].5 (5). pp 36-41. Available:

https://www.jabonline.in/abstract.php?article_id=238\&sts=2

[30] H. A Mohammad (July 2008). Response of African Catfish, Clarias gariepinus, to different dietary protein and lipid levels in practical diets. J. World Aquacul. Soc. [Online]. 39 (4). pp 541 - 548 Available: https://onlinelibrary.wiley.com/doi/abs/10.1111/j.17497345.2008.00178.x.

[31] O. A. Fabgenro and K. Jauncey (1995). Growth and protein utilization by juvenile catfish (Clarias gariepinus) fed dry diets containing co-dried lactic acid - fermented fish silage and protein feedstuffs. Bioresource technol. [Online]. 51(1). pp 29-35. Available: https://doi.org/10.1016/0960-8524(94)00064-8.

[32] L. C. Nawnna (2003). Nutritional value and digestibility of fermented shrimp head waste meal by African catfish Clarias gariepinus. Pakistan J Nutr. [Online]. 2 (6). pp 339-345. Available https://scialert.net/abstract/?doi=pjn.2003.339.345.

[33] C. C. Ngugi, J. R. Bowman and B. O. Omolo A new guide to fish farming in Kenya; Corvallis Oregon: Aquaculture CRSP office 2007, 95p.

[34] O. A. Aniebo, E. S. Erondu and Owen O. J. (2009). Replacement of fish meal with maggot meal in African catfish Clarias gariepinus diets. Revista UDO Agricola [Online]. 9(3). pp 666-671. Available: http://www.bioline.org.br/request?cg0.

[35] C. Brauge, G. Corraze and Medale F. (May 1995). Effect of dietary levels of carbohydrate and lipid on glucose oxidation and lipogenesis from glucose in rainbow trout Oncorhynchus mykiss reared in freshwater or in seawater. Comparat. Biochemist. Physiol. [Online]. 111 (1). pp 117-124. Available: https://www.sciencedirect.com/science/article/abs/pii/030096299598 527N?via\%3Dihub.

[36] J. Dias, R. Rueda-Jasso, S. Panserat L. E. C. D. Conceiçã, E. F. Gomes and M. T. Dinis, (September 2004). Effect of dietary carbohydrate-to-lipid ratios on growth, lipid deposition and metabolic hepatic enzymes in juvenile Senegalese sole (Solea Senegalensis, Kaup). Aquac. Res. [Online]. 35 (12). pp 1122-1130. Available : https://doi.org/10.1111/j.1365-2109.2004.01135.x.

[37] N. Richard, "Effet du taux et de la nature des lipides alimentaires sur les mécanismes intervenant dans la constitution des dépôts lipidiques (transport, captage, synthèse) chez la truite Arc-en-ciel et le bar”. $\mathrm{Ph}$ $\mathrm{D}$ thesis dissertation, École doctorale des sciences du vivant, géosciences, sciences de l'environnement, Université de Bordeaux I, France. 2006

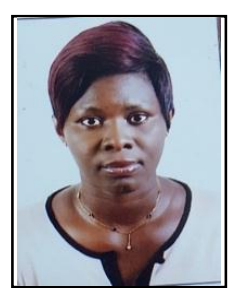

Ehoulaman Marie-Angèle N'gbaramou is a $\mathrm{PhD}$ degree student in Foods and Sciences Technology of the Nangui Abrogoua University, Abidjan, Côte d'Ivoire. She is also junior researcher associate to the Aquaculture Department of CRO (Centre de Recherches Océanologiques), Abidjan Côte d'Ivoire. She has a Master degree in Foods and Sciences Technology from Nangui Abrogoua University (2014).

She participates of the project of "the development of the competitive fish feeds formulas by Cote d'Ivoire fish farming agro- 
ecological areas" in collaboration of AISA (Association Ivoirienne des Sciences Agronomiques) and CRO (Centre de Recherches Océanologiques), Abidjan, Côte d'Ivoire. She works on the development of the locally feeds for the different growth stages of catfish Clarias gariepinus. She has co-auteur of one scientific publication related of feeds, feeding and growth of Clarias gariepinus fingerlings (2019).

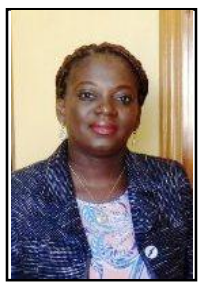

Ahou Rachel Koumi is a scientist in the focus of Biochemistry and Nutrition to the Aquaculture Department of the Oceanological Research Center of Abidjan, Côte d'Ivoire. She has PhD. in the Foods Sciences and Technology from Nangui Agrogoua University of Côte d'Ivoire (2010). She has also certificates in the valorization of research results and innovation. She has professional experience in the field of fish nutrition and feeding.

She has contributed to the realization of several projects of the development of aquaculture of Côte d'Ivoire which are "the diffusion of the technologies of low cost production and improvement of the quality of Catfish Clarias gariepinus in Côte d'Ivoire", " the development of the competitive fish feeds formulas by Côte d'Ivoire fish farming agroecological areas", "the increasing of the survival and growth of the catfish post larvae in Côte d'Ivoire", "the identification of the indicators of the performance for the feeding of the farmed fish in fish farming areas of the Côte d'Ivoire".

She collaborates in the supervision of students at the PhD., engineer and master levels in Aquaculture and fish nutrition. She accounts for more than twenty scientific publications. She is a member of AISA (Association Ivoirienne des Sciences Agronomiques) and AFEMCI (Association des Femmes Chercheurs de Côte d'Ivoire).

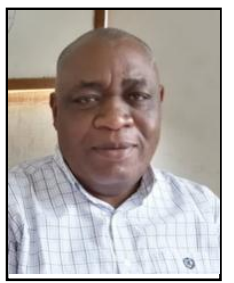

Boua Célestin Atsé is the President of the AISA (Association Ivoirienne des Sciences Agronomiques) from Côte d'Ivoire Based in Abidjan; West of Africa. $\mathrm{He}$ has $\mathrm{PhD}$. in Oceanography with the focus in Aquaculture of the Institute of ISMER (Institut des Sciences de la Mer) of the University of Quebec at Rimouski, Canada since 1998.

He has professional experience in the coordination of projects of the aquaculture, health risk evaluation due to the farming fish, identification of aquaculture sites, development of local fish feeds, growth and survival of post-larvae, farming practices, fishing, hydrobiology and oceanography. He is in charge of several research programs in the Aquaculture Department of CRO (Centre de Recherches Océanologiques) of Côte d'Ivoire where he works as senior researcher. $\mathrm{He}$ is an associated professor to the training of the students in the several universities of Côte d'Ivoire.

$\mathrm{He}$ is also member of the board of directors of the CNRA (Centre National de Recherches Agronomiques) of Côte d'Ivoire and collaborates with several national and international institutions including association of fish farmers of Côte d'Ivoire, FAO, etc.

He participated in the supervision of more than $20 \mathrm{PhD}$. scientists' level and is co-author for more than a hundred scientific articles published in the fields of aquaculture, bio-ecology, hydrobiology, genetics and chemistry. He has won several training fellowships, including the Fulbright Foreign fellowships Program from USA.

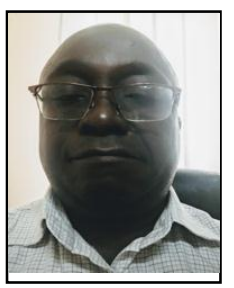

Kablan Tano is a Full Professor of Foods Sciences and Technologies since 1999 in the NANGUI ABROGOUA University based in Abidjan, Côte d'Ivoire. He has a PhD. in Food Science and Technology of Laval University of Quebec, Canada. He has also a rural engineering diploma obtained at the Rural Equipment Engineer School of Ouagadougou, Burkina Faso (1991). He spent two years (1986 to 1988) in the preparation classes in higher and special mathematics at the ENSTP (Ecole Nationale Supérieure des Travaux Publics) of Yamoussoukro, Côte d'Ivoire.

He has professional experience in the processing and preservation of foods products particularly fresh fruit and vegetables. He has also specialized in packaging and modification of packaging atmosphere design He is collaborating researcher of the Horticulture Research Center of Laval University in Quebec (Canada) and the Department of Plant Agriculture at the University of Guelph in Ontario, Canada.
$\mathrm{He}$ is also working in formulation of fish feeds in collaboration with the CRO (Centre de Recherches Océanologiques), Abidjan, Côte d'Ivoire. He has professional experience in the scientific projects coordination and management. He participated in the supervision of several $\mathrm{PhD}$. Level students training and he is co-author for the lot of publications in the fields of aquaculture, foods processing and conservation and improvement of the duration of fresh fruit and vegetables conservation.

and the other authors may include biographies at the end of regular papers. 